УДК $347+342.9(477)$

DOI https://doi.org/10.32837/pyuv.v0i3(32).605

I. П. Сторожук

orcid.org/0000-0003-3104-6071

кандидат юридичних наук, доцент,

доцент кафедри конституиійного, адміністративного та фінансового права Хлельницького університету управління та права ілені Леоніда Юзькова

\title{
ІНФОРМАЦІЙНЕ ПРАВОПОРУШЕННЯ ЯК ПІДСТАВА АДМІНІСТРАТИВНОЇ ВІДПОВІДАЛЬНОСТІ
}

Інформація завжди супроводжувала людину та відігравала важливу роль у формуванні соціальних зв’язків. Інформаційна революція, яка відбулась в останні десятиліття, сприяла стрімкому розвитку інформаційних технологій, систем управління та зв'язку, що привело не лише до позитивного розширення інформаційних відносин, але й до появи негативних явищ (інформаційна зброя, інформаційні війни, кіберзлочинність тощо). Дані процеси не могли залишитись поза увагою науковців, саме тому останнім часом у наукових колах багато уваги приділяють питанням збереження та захисту інформації в різних сферах життедіяльності людини, суспільства, держави. Однак коли питання стосується відповідальності за інформаційні правопорушення, то переважно акцентується увага на більш суспільно небезпечній їхній складовій частині, а саме на інформаційних злочинах. Інформаційні проступки досліджуються або частково, або щодо певної категорії проступків. Наприклад, І.П. Кушнір досліджуе адміністративну відповідальність за інформаційні проступки у прикордонній сфері [1, с. 45-51], Ю.І. Савченко - у сфері контролю за додержанням податкового законодавства [2, с. 138-141].

Безпосередньо проблематика адміністративної відповідальності в галузі обігу інформації висвітлена у працях Ч.Н. Азімова, І.Л. Бачило, А.Б. Венгерова, С.Д. Волошко, В.А. Дозорцева, В.І. Жукова, В.О. Калятіна, Л.П. Коваленка, А.Т. Комзюка, В.А. Ліпкана, Д.М. Лук'янця, Ю.Є. Максименко, О.А. Підопригори, В.В. Сидоренка, О.О. Тихомирова, Р.Б. Шишка, О.А. Чобота й інших.

Поняття адміністративної відповідальності за інформаційні проступки є досить дискусійним у наукових колах. Неоднозначність підходів спричинена відсутністю в законодавстві чіткого визначення як поняття адміністративної відповідальності, так і поняття «інформаційні проступки».

Активність дискусій щодо правової категорії «адміністративна відповідальність» значною мірою зумовлена, по-перше, широтою застосування цього терміна в юридично-науковій, правозастосовній, загальноосвітній сферах і на побутовому рівні, по-друге, двоїстою позицією законодавця, який уживає цей термін у численних нормативних актах, але не дає його визначення [3, с. 227].

Чинне законодавство не містить конкретного визначення поняття адміністративної відповідальності, хоча в Кодексі України про адміністративні правопорушення (далі - КУпАП) є гл. 2 «Адміністративне правопорушення та адміністративна відповідальність». У ст. 9 цієї глави дано визначення адміністративного правопорушення (проступку) та вказано, що саме воно є підставою для адміністративної відповідальності.

За відсутності законодавчого визначення дану правову категорію досліджують і формулюють науковці. Проведений аналіз наукових джерел свідчить про різноманітність поглядів науковців щодо визначення суті адміністративної відповідальності як правової категорії. Наведемо кілька наукових формулювань даної правової категорії.

Адміністративна відповідальність - це специфічне реагування держави на адміністративне правопорушення, що полягає в застосуванні уповноваженим органом або посадовою особою передбаченого законом стягнення до суб'єкта правопорушення [6].

Адміністративна відповідальність - це різновид правової відповідальності, специфічна форма негативного реагування з боку держави в особі iï компетентних органів на відповідну категорію протиправних проявів (передусім адміністративних проступків), згідно з якою особи, що скоїли ці правопорушення, повинні дати відповідь перед повноваженим державним органом за свої неправомірні дії і понести за це адміністративні стягнення в установлених законом формах і порядку [4].

Адміністративна відповідальність - це вид юридичної відповідальності фізичних і юридичних осіб, яка полягає в застосуванні уповноваженими державою публічними органами (їх посадовими особами) певного виду адміністративного примусу - адміністративного стягнення (адміністративної санкції) [5].

Як видно з наведених визначень, науковці формулюють по-різному дану категорію, усіх вони згадують про прив'язку до адміністративного правопорушення чи адміністративної санкції. Це логічно, бо якщо адміністративне правопорушення 
є підставою для відповідальності, то адміністративне стягнення, як санкція за вчинене правопорушення, є передбаченою у ст. 23 КУпАП мірою відповідальності.

Усі наявні види адміністративних стягнень тісно пов'язані один з одним і утворюють єдину систему. Їх насамперед об’єднує загальна мета захист правопорядку, виховання осіб, що вчинили адміністративні проступки, у дусі дотримання законів, а також запобігання скоєнню нових проступків як правопорушниками, так і іншими особами. Кожне стягнення є покаранням, мірою відповідальності, призначеної за проступки, а застосування будь-якого стягнення означає настання адміністративної відповідальності і спричиняє для винного несприятливі юридичні наслідки [6].

Що стосується безпосередньо адміністративної відповідальності, то в ч. 2 ст. 9 КУпАП зазначено, що «адміністративна відповідальність за правопорушення, передбачені цим Кодексом, настає, якщо ці порушення за своїм характером не тягнуть за собою відповідно до закону кримінальної відповідальності». Тобто можна зробити висновок, що правопорушення, які не передбачені КУпАП, не підпадають під адміністративну відповідальність. Однак даний висновок неправильний.

Інститут адміністративної відповідальності $€$ одним із важливих інститутів адміністративного права, який виступає необхідним засобом охорони громадського порядку і якому притаманні всі ознаки юридичної відповідальності. За допомогою цього інституту здійснюється захист не тільки адміністративно-правових відносин, а й відносин, урегульованих нормами фінансового, екологічного, трудового, митного, іноді й цивільного, права та процесуальних галузей [4]. Наступає адміністративна відповідальність і за інформаційні проступки.

Інститут адміністративної відповідальності в інформаційній сфері має своєрідну специфіку правового регулювання, що зумовлено природою інформаційних правовідносин. Як зазначає O.К. Тугарова, специфічні ознаки інституту адміністративної відповідальності в інформаційній сфері такі: 1. За допомогою цього інституту здійснюється захист не тільки адміністративно-правових відносин, а й відносин, урегульованих нормамиіншихгалузейправа, зокремаінформаційного, банківського, фінансового, медіаправа тощо. 2. Підставою для адміністративної відповідальності є вчинення правопорушення (проступку), передбаченого нормами КУПАП та іншим законами, що регулюють порядок створення, збирання, одержання, зберігання, використання, поширення, охорони та захисту інформації. 3. Перелік заходів адміністративної відповідальності, що застосовуються до особи, яка вчинила адміністративне правопорушення в інформаційній сфері, є дещо ши- ршим і не завжди закріплений у нормах КУпАП, проте за своєю юридичною природою такі заходи є адміністративним стягненням і не виключають можливості настання адміністративної відповідальності. 4. Повноваження органів, які в межах своєї компетенції наділені правом застосовувати адміністративні стягнення за адміністративні правопорушення в інформаційній сфері, визначаються в нормативних приписах КУпАП та інших нормативно-правових актах, якими врегульовано порядок створення, збирання, одержання, зберігання, використання, поширення, охорони та захисту інформації в Україні [10, с. 79].

У межах теми нашого дослідження наступне, що потребує уточнення, це визначення інформаційного правопорушення (проступку) як підстави для адміністративної відповідальності. Погоджуємося з А.В. Кирилюк і можемо стверджувати, що «сутність зв'язку правопорушення 3 інформацією виявляється в його посяганні на певний порядок, правовідносини, серед яких, в інформаційному ракурсі, виділяються достатньо сформовані сукупності:

- по-перше, щодо формування й використання інформаційних ресурсів на основі створення, збирання, оброблення, накопичення, зберігання, пошуку, поширення й надання інформації;

- по-друге, щодо створення й застосування інформаційних технологій та засобів їхнього забезпечення;

- по-третє, щодо захисту інформації та прав суб'єктів інформаційних відносин» [7, с. 52].

Більшість дослідників інформаційного права розглядають інформаційне правопорушення, а не інформаційний проступок. Під час дослідження порушення інформаційно-правових норм загалом логічне застосування категорії «інформаційне правопорушення», бо вона охоплює всі правопорушення, що є інформаційними за змістом і за формою. Інформаційним правопорушенням $€$ те правопорушення, що завдає шкоди (небезпеки) інформаційним правам чи свободам людини та громадянина, інформаційній інфраструктурі держави чи скоюється за допомогою інформаційно-телекомунікаційних технологій або засобів зв'язку [8]. Таке розширене поняття інформаційного правопорушення охоплює і злочини, і проступки у сфері обігу інформації. Потрібно зауважити, що «інформаційний проступок» - поняття збірне, складається із проступків у сфері обігу інформації в різних галузях права. Інформаційні проступки можуть бути в адміністративній, цивільній, трудовій, фінансовій, податковій, кримінальній та інших галузях.

Отже, якщо розглядати інформаційні правопорушення, за які передбачається адміністративна відповідальність, то потрібно конкретизувати їх саме за видовою ознакою, тобто вживати термін 
«адміністративно-інформаційні правопорушення (проступки)». Під адміністративно-інформаційним правопорушення (проступком) потрібно розуміти протиправну, суспільно шкідливу, винну (умисну або необережну) дію чи бездіяльність, що може завдати або завдає шкоди та посягає на врегульовані законами суспільні відносини у сфері обігу (одержання, використання, поширення та зберігання) інформації, за яку законодавством передбачено адміністративну відповідальність.

Потрібно також зауважити, що вичерпного переліку адміністративно-інформаційних правопорушень (проступків) в одному нормативному акті немає. Тому можемо розглядати адміністративно-інформаційні правопорушення (проступки), що містяться в Кодексі України про адміністративні правопорушення [9], й адміністративно-інформаційні правопорушення (проступки), що містяться в інших нормативно-правових актах (як-от Податковий кодекс України, Бюджетний кодекс України, Закон України «Про телекомунікації» тощо).

Адміністративні інформаційні правопорушення, зазначені в КУпАП, також не систематизовано в окремому розділі, а розпорошено в різних його розділах (главах). У КУпАП є понад сто статей, якими передбачено відповідальність за інформаційні проступки, однак всі вони стосуються порушення права на окремі види інформації, розголошення інформації, несвоєчасне надання інформації, неповне надання інформації, надання недостовірної інформації, відмови в наданні інформації, приховування інформації, недбалого зберігання, псування або ж втрати інформації.

Основою класифікації адміністративних правопорушень у сфері обігу інформації можуть виступати різні критерії - види інформації, напрями інформаційної діяльності, режими доступу до інформації тощо. Проте найбільш виправданою вбачається класифікація, в основі якої лежить такий критерій, як родовий об’єкт, тобто група тотожних, однорідних суспільних відносин, що охороняються комплексом адміністративноправових норм і містяться в Особливій частині КУПАП [10, с. 82].

Кодекс України про адміністративні правопорушення передбачає адміністративну відповідальність за: адміністративні правопорушення в галузі охорони праці і здоров'я населення (гл. 5 КУпАП); адміністративні правопорушення, що посягають на власність (гл. 6 КУпАП); адміністративні правопорушення в галузі охорони природи, використання природних ресурсів, охорони пам'яток історії та культури (гл. 7 КУпАП); адміністративні правопорушення на транспорті, у галузі шляхового господарства і зв'язку (гл. 10 КУпАП); адміністративні правопорушення в галузі торгівлі, громадського харчування, сфері послуг, у галузі фінансів і підприємницькій діяльності (гл. 12 КУпАП); адміністративні правопорушення, пов'язані з корупцією (гл. 13-а КУпАП); адміністративні правопорушення, що посягають на громадський порядок і громадську безпеку (гл. 14 КУпАП); адміністративні правопорушення, що посягають на встановлений порядок управління (гл. 15 КУпАП); адміністративні правопорушення, що посягають на здійснення народного волевиявлення та встановлений порядок його забезпечення (гл. 15-а КУпАП).

Незважаючи на велику кількість статей у КУПАП, що охоплюють інформаційні проступки в різних сферах життєдіяльності людини, назвати цей перелік вичерпним не можна. Крім того, зміни в соціальній, економічній, політичних сферах держави потребують кореляції й охоронюваних державою інтересів.

Як приклад візьмемо сферу інформаційної безпеки держави. Здавалось би, у КУпАП прописані більше десятка статей, об'єктом порушень яких є медіапростір. Однак у результаті проведеного аналізу їхного змісту можемо стверджувати, що дані статті стосуються багатьох аспектів функціонування медіапростору (ст. 146 КУпАП - порушення правил реалізації, експлуатації радіоелектронних засобів та випромінювальних пристроїв, а також користування радіочастотним ресурсом України; ст. 147 КУпАП - порушення правил охорони ліній і споруд зв'язку; ст. 148-1 КУпАП - порушення Правил надання та отримання телекомунікаційних послуг; ст. 148-3 КУПАП - використання засобів зв'язку з метою, що суперечить інтересам держави, з метою порушення громадського порядку та посягання на честь і гідність громадян; ст. 164-7 КУПАП - порушення умов розповсюдження і демонстрування фільмів, передбачених державним посвідченням на право розповсюдження і демонстрування фільмів; ст. 188-7 КУпАП невиконання законних вимог національної комісії, що здійснює державне регулювання у сфері зв'язку й інформатизації; та інші), окрім тих, що нині стали актуальними і такими, що мають величезний вплив на формування ставлення до держави чи суспільних процесів, - це встановлення відповідальності за зміст та якість медіаконтенту радіо- та телеорганізацій.

У наукових колах час від часу порушується питання про необхідність винесення всіх складів інформаційних правопорушень в окремий розділ КУпАП. Так, А.О. Волкова стверджує, що «для запровадження ефективної правової регламентації адміністративної відповідальності за правопорушення в інформаційній сфері потрібно внести зміни до КУПАП шляхом виділення окремого розділу, у якому було б закріплено вичерпний перелік правопорушень у сфері обігу інформації» $[11$, с. 78]. Уважаємо це нелогічним, недоречним 
і таким, що тільки створить додаткові труднощі в користуванні Кодексом.

Натомість було б бажаним більш чітко прописати у статтях, хто і за яку саме інформацію може бути протягнений до адміністративної відповідальності. Деякі автори стверджують, що підставою для адміністративної відповідальності повинні бути порушення, пов'язані з обігом службової інформації. Однак це не завжди випливає зі змісту адміністративної норми. Наприклад, ст. 173-1 «Поширювання неправдивих чуток». Суб'єктом даного правопорушення може бути будь-яка дієздатна особа, а такими чутками визнається будь-яка інформація, що може спричинити паніку серед населення чи загрожує громадському порядку. Крім того, чутки, будучи інформацією, аж ніяк не можуть бути віднесенні до службової інформації.

Отже, підбиваючи підсумок, потрібно зазначити, що адміністративне законодавство стосовно регулювання інформаційних відносин є недосконалим і потребує цілої низки змін та доповнень, що узгодило б його із сучасними реаліями, упорядкувало правову регламентацію інформаційних відносин, порушення яких призводить до адміністративної відповідальності. Складовими частинами цього процесу мають бути: внесення в КУПАП визначення таких термінів, як «адміністративна відповідальність» та «інформаційний проступок»; у чинних статтях потрібно більш конкретно виписати, хто, за яку чи стосовно якої інформації може бути протягнений до адміністративної відповідальності; також потрібно постійно, відповідно до змін у соціальній, економічній, політичних сферах, вносити зміни та додавати нові склади адміністративно-інформаційних проступків із метою охорони державних і суспільних інтересів.

\section{Jimepamypa}

1. Кушнір І.П. Адміністративна відповідальність за порушення законодавства про інформацію у прикордонній сфері. Інфорлація і право. 2019. № 1 (28). C. $45-51$.

2. Савченко Ю.І. Система адміністративно-правового регулювання інформаційної діяльності суб'єктів, що здійснюють контроль за додержанням податкового законодавства. Право і суспільство. 2017. № 3. Ч. 2. С. $138-141$.

3. Юридична відповідальність за правопорушення в інформаційній сфері та основи інформаційної деліктології : монографія / І.В. Арістова та ін. ; за заг. ред. К.І. Бєлякова. Київ : КВІЦ, 2019. 344 с.

4. Адміністративне право. Загальна частина : навчальний посібник / С.М. Алфьоров та ін. Луганськ : Центр навчальної літератури, 2011. 216 с. URL: https://pidru4niki.com/19310227/pravo/ administrativna_vidpovidalnist.

5. Адміністративне право України. Повний курс : підручник / В.В. Галунько та ін. Херсон : Олді-Плюс, 2018. 446 c.
6. Адміністративна відповідальність: характеристика та накладення адміністративних стягнень. URL: https://ru.osvita.ua/vnz/reports/law/9769/.

7. Кирилюк А.В. Поняття та види інформаційних правопорушень. Часопис иивілістики. 2017. Вип. 26. C. $51-55$.

8. Максименко Ю.Є. Інформаційні правопорушення: поняття та ознаки. GOAL. 2014. URL: http://goal-int.org/informacijni-pravoporushennyaponyattya-ta-oznaki/.

9. Кодекс України про адміністративні правопорушення : Закон України. Відолості Верховної Ради Української Радянської Соціалістичної Республіки. 1984. Дод. до № 50. Ст. 1122.

10. Тихомиров О.О., Тугарова О.К. Юридична відповідальність за правопорушення в інформаційній сфері : навчальний посібник. Київ : Нац. акад. СБУ, 2015. 172 c.

11. Волкова А.О. Особливості юридичної відповідальності за правопорушення в інформаційній сфері. Правова інфорлатика. 2014. № 1 (14). С. 72-80.

\section{Анотація}

Сторожук I. П. Інформаційне правопорушення як підстава адміністративної відповідальності. - Стаття.

Більшість дослідників інформаційного права розглядають інформаційне правопорушення, а не інформаційний проступок. Якщо досліджувати порушення інформаційно-правових норм загалом, логічним $є$ застосування саме категорії «інформаційне правопорушення», бо вона охоплює всі правопорушення, що є інформаційними за змістом і за формою. Таке розширене поняття інформаційного правопорушення охоплює i злочини, і проступки у сфері обігу інформації. Потрібно зауважити, що «інформаційний проступок» - поняття збірне, складається із проступків у сфері обігу інформації в різних галузях права: адміністративній, цивільній, трудовій, фінансовій, податковій, кримінальній та інших.

Якщо розглядати інформаційні правопорушення, за які передбачається адміністративна відповідальність, то потрібно конкретизувати їх саме за видовою ознакою, тобто вживати термін «адміністративно-інформаційні правопорушення (проступки)». Під адміністративно-інформаційним правопорушення (проступком) потрібно розуміти протиправну, суспільно шкідливу, винну (умисну або необережну) дію чи бездіяльність, що може завдати або завдає шкоди та посягає на врегульовані законами суспільні відносини у сфері обігу (одержання, використання, поширення та зберігання) інформації, за яку законодавством передбачено адміністративну відповідальність.

Адміністративне законодавство стосовно регулювання інформаційних відносин є недосконалим і потребує цілої низки змін та доповнень, що впорядкувало б правову регламентацію інформаційних відносин, порушення яких призводить до адміністративної відповідальності. Складовими частинами цього процесу мають бути: внесення в Кодекс України про адміністративні правопорушення визначення таких понять, як «адміністративна відповідальність» та «інформаційний проступок»; у чинних статтях потрібно більш конкретно виписати, хто, за яку чи стосовно якої інформації може бути протягнений до адміністративної відповідальності; також потрібно постійно, відповідно до змін у соціальній, економічній, політичних сферах, вносити зміни та додавати нові склади адміністративно-ін- 
формаційних проступків із метою охорони державних та суспільних інтересів.

Ключові слова: інформаційне правопорушення, інформаційний злочин, інформаційний поступок, адміністративно-інформаційне правопорушення, адміністративно-інформаційний проступок.

\section{Summary}

Storozhuk I. P. Information offense as a basis for administrative liability. - Article.

Most information law researchers consider the information offense to be an information misconduct. Investigating violations of information and legal norms, in general, it is logical to use the category of "information offense" because it covers all offenses that are informational in content and form. This extended concept of information offense covers both crimes and misdemeanors in the field of information circulation. It should be noted that the concept of information misconduct is a collective and consists of misdemeanors in the field of information circulation in various branches of law: administrative, civil, labor, financial, tax, criminal and others.

If we consider information offenses for which administrative liability is provided, it is necessary to specify them on a specific basis, i.e. to use the term "administrative and information offenses (misdemeanors)". An administrative-information offense (misdemeanor) should be understood as an illegal, socially harmful, culpable (intentional or negligent) act or omission) that may cause or is causing harm and encroaches on the social relations regulated by law in the sphere of circulation (receipt, use, distribution and storage) of information for which the legislation provides for administrative liability.

Administrative legislation on the regulation of information relations is imperfect and requires a number of changes and additions that would regulate the legal regulation of information relations, the violation of which entails administrative liability. The components of this process should be: the introduction in the Code of Administrative Offenses of the definition of such definitions as "administrative liability" and "information misconduct"; in the current articles it is necessary to write more specifically who, for what or in relation to what information can be brought to administrative responsibility; it is also necessary to constantly, in accordance with changes in the social, economic, political spheres, make changes and add new components of administrative and information misconduct in order to prevent and protect state and public interests.

Key words: information offense, information crime, information concession, administrative-information offense, administrative-information offense. 